\title{
Growth components and zinc recovery efficiency of upland rice genotypes
}

\author{
Nand Kumar Fageria(1) and Virupax Chanabasappa Baligar(2)
}

\begin{abstract}
(1)Embrapa Arroz e Feijão, Caixa Postal 179, CEP 75375-000 Santo Antônio de Goiás, GO, Brazil. E-mail: fageria@cnpaf.embrapa.br (2)USDA-ARS-ACSL, Beltsville Agricultural Research Center, Beltsville, MD 20705-2350, USA. E-mail: vbaligar@asrr.arsusda.gov
\end{abstract}

\begin{abstract}
The objective of this work was to evaluate Zn use efficiency by upland rice genotypes. The experiment was carried out in a greenhouse, with ten upland rice genotypes grown on an Oxisol (Typic Hapludox) with no application, and with application of $10 \mathrm{mg} \mathrm{kg}^{-1} \mathrm{Zn}$, applied as zinc sulfate. Shoot dry weight, grain yield, Zn harvest index, Zn concentration in shoot and in grain were significantly influenced by soil Zn levels and genotypes. However, panicle number and grain harvest index were significantly affected only by genotype. Genotypes CNA8557, CNA8540 and IR42 produced higher grain yield than other genotypes. Genotypes showed significant variability in $\mathrm{Zn}$ recovery efficiency. On average, 13\% of the applied Zn was recovered by upland rice genotypes. Genotypes with high Zn recovery efficiency could be used in breeding of Zn efficient upland rice cultivars. Higher level of soil Zn (10 mg kg-1) increased significantly the concentrations of plant $\mathrm{Cu}$ and $\mathrm{Mn}$. However, Fe concentrations in plant (shoot and grain) were not influenced by soil Zn levels.
\end{abstract}

Index terms: Oryza sativa, grain yield, grain harvest index, zinc harvest index.

\section{Componentes de crescimento e eficiência de recuperação de zinco de genótipos de arroz de terras altas}

\begin{abstract}
Resumo - O objetivo deste trabalho foi avaliar a eficiência no uso do zinco por genótipos de arroz. O experimento foi conduzido em casa de vegetação, utilizando-se dez genótipos de arroz de terras altas, cultivados num Latossolo Vermelho distrófico, com dois níveis de Zn: sem aplicação de Zn e com aplicação de 10 mg kg-1 de solo na forma de sulfato de zinco. A massa de matéria seca da parte aérea, produção de grãos, índice de colheita de Zn, concentração de Zn na parte aérea e grãos foram significativamente influenciados pelos níveis de Zn e genótipos. Porém, o número de panículas e o índice de colheita de grãos foram significativamente influenciados somente pelos genótipos. Os genótipos CNA8557, CNA8540 e IR42 foram os mais produtivos. Os genótipos mostraram variação significativa na recuperação de Zn. Em média, 13\% do Zn aplicado foi recuperado pelos genótipos. Os genótipos com alta capacidade de recuperação de Zn podem ser utilizados no programa de melhoramento, para desenvolvimento de cultivares de arroz de terras altas eficientes no uso de $\mathrm{Zn}$. A dose de $10 \mathrm{mg} \mathrm{kg}^{-1}$ aumentou a concentração de Cu e Mn na parte aérea e grãos, porém a concentração de Fe na parte aérea e nos grãos não foi influenciada pelos níveis de zinco.
\end{abstract}

Termos para indexação: Oryza sativa, rendimento de grãos, índice de colheita de grãos, índice de colheita de zinco.

\section{Introduction}

Upland rice (Oryza sativa L.), also known as aerobic rice, grows generally on undulating lands and depends totally on rainfall for water supply. This crop is mainly grown in the central part of Brazil, which is locally known as the "Cerrado" region. Most of the soils of the region are Oxisols and Ultisols, presenting low fertility (Lopes, 1983; Goedert, 1989); Zn deficiency in upland rice grown on these soils is widely reported (Fageria et al., 1997; Fageria, 2001). The main reason for deficiency in highly weathered acidic Cerrado soils is that these soils are inherently low in total and available Zn. Furthermore, liming is an essential practice to reduce soil acidity and to improve crop yield on these soils. However, increased soil $\mathrm{pH}$ due to liming tends to increase $\mathrm{Zn}$ deficiency in crop plants (Fageria et al., 2002).

The $\mathrm{Zn}$ requirement can be easily met by a genotype or cultivar that is efficient in uptake and utilization of low levels of soil available $\mathrm{Zn}$. Genotypic variations in Zn uptake and utilization in $\mathrm{Zn}$ deficient soils have been reported (Graham \& Rengel, 1993; Fageria et al., 2002). 
However, only limited data are available concerning variation in Zn use efficiency among upland rice genotypes.

The objective of this work was to evaluate $\mathrm{Zn}$ use efficiency by upland rice genotypes.

\section{Material and Methods}

A greenhouse experiment was conducted at Embrapa Arroz e Feijão, in Santo Antônio de Goiás, GO, Brazil, to evaluate Zn use efficiency of ten upland rice genotypes. The soil used was an Oxisol (clayey, kaolinite, isothermic Typic Hapludox), presenting the following chemical and textural properties, before application of $\mathrm{Zn}$ treatments: pH 4.2 (1:2.5 soil-water ratio), extractable $\mathrm{P}$ of $0.6 \mathrm{mg} \mathrm{kg}^{-1}$, extractable $\mathrm{K}$ of $50 \mathrm{mg} \mathrm{kg}^{-1}$, extractable Ca of $0.27 \mathrm{cmol}_{\mathrm{C}} \mathrm{kg}^{-1}$, extractable $\mathrm{Mg}$ of $0.12 \mathrm{cmol}_{\mathrm{C}} \mathrm{kg}^{-1}$, extractable $\mathrm{Al}$ of $0.9 \mathrm{cmol}_{\mathrm{C}} \mathrm{kg}^{-1}$, extractable $\mathrm{Cu}$ of $1.2 \mathrm{mg} \mathrm{kg}^{-1}$, extractable $\mathrm{Zn}$ of $0.7 \mathrm{mg} \mathrm{kg}^{-1}$, extractable Fe of $60 \mathrm{mg} \mathrm{kg}^{-1}$, extractable Mn of $10 \mathrm{mg} \mathrm{kg}^{-1}$, and organic matter of $20 \mathrm{~g} \mathrm{~kg}^{-1}$. Textural analysis values were $435 \mathrm{~g} \mathrm{~kg}^{-1}$ clay, $200 \mathrm{~g} \mathrm{~kg}^{-1}$ silt and $365 \mathrm{~g} \mathrm{~kg}^{-1}$ sand. Phosphorus and K were extracted by the Mehlich-1 extracting solution. Phosphorus was determined by colorimetry, and $\mathrm{K}$ by flame photometry. Calcium, Mg, and $\mathrm{Al}$ were extracted with $1 \mathrm{~mol} \mathrm{~L}^{-1} \mathrm{KCl}$. Aluminum was determined by titration with $\mathrm{NaOH}$, and $\mathrm{Ca}$, and Mg by titration with EDTA. Micronutrients were determined on a portion of the extract of $\mathrm{P}$ by atomic absorption spectrophotometry. Organic matter was determined by the Walkley-Black method, and textural analysis by the pipette method. Soil analysis methods used in this study are described in a soil analysis manual published by Embrapa (1997).

Treatments consisted of two Zn levels, low $\left(0 \mathrm{mg} \mathrm{kg}^{-1}\right)$ and high (10 $\left.\mathrm{mg} \mathrm{kg}^{-1}\right)$, applied as zinc sulfate, and ten upland rice genotypes (Bonança, Caiapó, Canastra, Carajás, Carisma, CNA8540, CNA8557, Guarani, Maravilha, IR42). A completely randomized design was used in a factorial arrangement with three replications. The study was conducted in plastic pots, each one containing $5 \mathrm{~kg}$ of soil. Pots received $10 \mathrm{~g}$ of dolomitic lime each, and were submitted to wetting and drying cycles for three weeks before sowing. The liming material had $27.4 \% \mathrm{CaO}$, $15.2 \% \mathrm{MgO}$, and a neutralizing power of 73\%. At sowing, in addition to $\mathrm{Zn}$ treatments, each pot received a basal application of $900 \mathrm{mg} \mathrm{N}$ as ammonium sulfate, $786 \mathrm{mg}$ $\mathrm{P}$ as triple superphosphate and $996 \mathrm{mg} \mathrm{K}$ as potassium chloride. Each pot also received a topdressing of $900 \mathrm{mg}$ $\mathrm{N}$ ammonium sulfate at active tillering (50 days after sowing). These basal liming, fertilizer rates and $\mathrm{N}$ topdressing were based on the recommendations of Fageria \& Baligar (1997). Each pot contained four plants, which were frequently watered to maintain moisture at approximate field capacity. Plants were harvested at maturity.

At harvest, grain yield, shoot dry weight and panicle numbers were determined. Plant material (shoot and grain) was dried in a forced-draft oven at about $70^{\circ} \mathrm{C}$ until constant weight and milled. Ground material was digested with 2:1 mixture of nitric and perchloric acids for chemical analysis. Micronutrients $\mathrm{Zn}, \mathrm{Cu}, \mathrm{Fe}$ and Mn were then analyzed by atomic absorption spectrophotometry. Grain harvest index (GHI), Zn harvest index $(\mathrm{ZnHI})$ and apparent $\mathrm{Zn}$ recovery efficiency (ARE-Zn) were calculated with the following equations:

GHI = Grain yield/(Grain + straw yield), yields are in g pot ${ }^{-1}$; $\mathrm{ZnHI}=\mathrm{Zn}$ uptake in grain/(Zn uptake in grain + straw), uptake is in mg pot $^{-1}$;

ARE-Zn $=\left[\left(\right.\right.$ Zn uptake in grain + straw in mg pot $^{-1}$ at higher Zn level - Zn uptake in grain + straw in mg pot $^{-1}$ at lower Zn level)/(Quantity of Zn applied in mg pot $\left.^{-1}\right] 100$.

All data were submitted to analysis of variance, and the $\mathrm{F}$ test was used to evaluate treatment significance. Tukey's test was used to compare treatment means at $5 \%$ probability level.

\section{Results and Discussion}

Shoot dry weight, grain yield, number of panicles, grain harvest index (GHI) and $\mathrm{Zn}$ harvest index ( $\mathrm{ZnHI}$ ) for ten adapted upland rice genotypes are presented in Table 1 . The first four plant parameters did not show significant interactions between $\mathrm{Zn}$ and genotypes (ZnxG). Therefore, results related to these parameters are presented across the two soil Zn levels. Nonsignificant ZnxG interaction indicates that genotypes behaved similarly at the two selected soil Zn levels. The ZnHI showed highly significant ZnxG interaction; therefore, data for this parameter are given at two Zn levels. However, upland rice genotypes can only be evaluated, for their Zn use efficiency, at each Zn level separately. During screening genotypes, care should be taken in selecting an appropriate $\mathrm{Zn}$ level. Such a $\mathrm{Zn}$ level in soil 
should not be too high or too low and should be based on earlier field observations (Fageria et al., 1997).

Shoot dry weight, grain yield and ZnHI were significantly affected by $\mathrm{Zn}$ level, as well as genotype treatment. However, number of panicles and GHI were significantly affected only by genotype treatment. Shoot dry weight varied from $58.43 \mathrm{~g} \mathrm{pot}^{-1}$ for Guarani to $96.26 \mathrm{~g} \mathrm{pot}^{-1}$ for IR42, with an average value of $75 \mathrm{~g} \mathrm{pot}^{-1}$. Similarly, grain yield varied from $52.93 \mathrm{~g} \mathrm{pot}^{-1}$ for Bonança to $71.33 \mathrm{~g} \mathrm{pot}^{-1}$ for CNA8557, with an average value of $62.51 \mathrm{~g} \mathrm{pot}^{-1}$. Snyder \& Carlson (1984) reported that shoot dry matter is positively correlated with grain yield in annual crops. However, Fageria \& Baligar (2001) reported that this relationship is quadratic in rice. This means that genotypes producing the highest grain yield should produce reasonably good dry matter yield. Highest grain yielding genotypes CNA8557, CNA8540 and IR42 produced maximal or near maximal amounts of shoot dry matter.

Number of panicles varied from 19.17 pot $^{-1}$ for cultivar Caiapó to 35.83 pot $^{-1}$ for cultivar IR42. The variation was $87 \%$ between highest panicle producing genotype IR42 and lowest panicle producing genotype. Panicle number showed a significant quadratic relationship with grain yield $\left(\mathrm{Y}=-16.0625+5.0294 \mathrm{X}-0.0746 \mathrm{X}^{2}, \mathrm{R}^{2}=0.61^{* *}\right)$. These results deal with Gravois \& McNew (1995). Fageria \& Baligar (1999) also reported that panicle per pot was the most important component of yield, accounting for $87 \%$ of the variation in rice grain yield.

Grain harvest index varied from 0.38 to 0.53 , with an average value of 0.46 . Efficiency of grain production in crop plants is frequently expressed as harvest index. Hay (1995) and Sinclair (1998) reported that grain harvest index is a trait associated with dramatic increases in crop yields. Grain harvest index reflects the partitioning of photosynthate between the grain and the vegetative part of the plant, and improvements in harvest index emphasize the importance of carbon allocation in grain production (Yoshida, 1981).

Upland rice in Brazil is totally dependent on rainfall for its water needs and is planted in wider row spacing than lowland or flooded rice (Fageria, 2001), to reduce plant competition for water. Such growth conditions generally result in taller plants and lower harvest index. However, in recent years, breeding has contributed to reduction in plant height, and Brazilian upland rice varieties are having harvest index levels near to flooded or lowland rice. Grain harvest indices of promising Brazilian upland rice genotypes used in this study are within the range of 0.40 to 0.49 , reported by Yoshida (1981) for lowland rice. The highest harvest index exhibited by California lowland rice cultivars under direct seeding was 0.59 (Roberts et al., 1993). Values of grain harvest indices of some genotypes reported have approached this value (Table 1). Recently, significant progress has occurred in improving grain harvest index of Brazilian upland rice cultivars.

Table 1. Shoot dry weight, grain yield, number of panicles, grain harvest index (GHI) (across two Zn levels) and Zn harvest index (ZnHI) of ten upland rice genotypes ${ }^{(1)}$.

\begin{tabular}{|c|c|c|c|c|c|c|}
\hline \multirow[t]{2}{*}{ Genotype } & \multirow{2}{*}{$\begin{array}{l}\text { Shoot dry wt. } \\
\left(\mathrm{g} \mathrm{pot}^{-1}\right)\end{array}$} & \multirow{2}{*}{$\begin{array}{l}\text { Grain yield } \\
\left(\mathrm{g} \mathrm{pot}^{-1}\right)\end{array}$} & \multirow[t]{2}{*}{ Panicles pot $^{-1}$} & \multirow[t]{2}{*}{ GHI } & \multicolumn{2}{|c|}{$\mathrm{ZnHI}$} \\
\hline & & & & & $\mathrm{Zn}_{0}$ & $\mathrm{Zn}_{10}$ \\
\hline Bonança & $64.25 \mathrm{ab}$ & $52.93 \mathrm{c}$ & $21.00 \mathrm{bc}$ & $0.45 \mathrm{ab}$ & $0.60 \mathrm{abc}$ & $0.25 \mathrm{ab}$ \\
\hline Caiapó & $89.52 \mathrm{de}$ & $55.60 \mathrm{bc}$ & $19.17 \mathrm{c}$ & $0.38 \mathrm{e}$ & $0.62 \mathrm{ab}$ & $0.25 \mathrm{ab}$ \\
\hline Canastra & $79.02 \mathrm{c}$ & $60.47 \mathrm{abc}$ & $24.00 \mathrm{abc}$ & $0.43 \mathrm{ab}$ & $0.64 \mathrm{ab}$ & $0.35 \mathrm{a}$ \\
\hline Carajas & $62.07 \mathrm{ab}$ & $60.67 \mathrm{abc}$ & $24.50 \mathrm{ab}$ & $0.50 \mathrm{~cd}$ & $0.76 a$ & $0.32 \mathrm{ab}$ \\
\hline Carisma & $70.38 \mathrm{a}$ & $61.82 \mathrm{abcd}$ & $26.17 \mathrm{ab}$ & $0.47 \mathrm{ab}$ & $0.60 \mathrm{abc}$ & $0.31 \mathrm{ab}$ \\
\hline CNA8540 & $66.85 \mathrm{ab}$ & $68.78 \mathrm{~d}$ & $25.83 \mathrm{ab}$ & $0.53 \mathrm{~cd}$ & $0.68 \mathrm{a}$ & $0.37 \mathrm{a}$ \\
\hline CNA8557 & $79.83 \mathrm{c}$ & $71.33 d$ & $26.83 \mathrm{a}$ & $0.47 \mathrm{ab}$ & $0.46 b c$ & $0.30 \mathrm{ab}$ \\
\hline Guarani & $58.43 b$ & 64.92abcd & $25.67 \mathrm{ab}$ & $0.53 \mathrm{~cd}$ & $0.70 \mathrm{a}$ & $0.22 \mathrm{~b}$ \\
\hline Maravilha & $83.98 \mathrm{ce}$ & $60.45 \mathrm{abc}$ & $27.33 \mathrm{a}$ & $0.42 \mathrm{ab}$ & $0.57 \mathrm{abc}$ & $0.26 \mathrm{ab}$ \\
\hline IR42 & $96.26 \mathrm{~d}$ & $68.15 d$ & $35.83 \mathrm{~d}$ & $0.41 \mathrm{ab}$ & $0.40 \mathrm{c}$ & $0.21 \mathrm{~b}$ \\
\hline Average & 75.06 & 62.51 & 25.63 & 0.46 & 0.60 & 0.28 \\
\hline \multicolumn{7}{|l|}{ F test } \\
\hline Zn level & $* *$ & $*$ & ns & $\mathrm{ns}$ & \multicolumn{2}{|c|}{$* *$} \\
\hline Genotype (G) & $* *$ & $* *$ & $* *$ & $* *$ & \multicolumn{2}{|c|}{$* *$} \\
\hline $\mathrm{ZnxG}$ & ns & $\mathrm{ns}$ & ns & $\mathrm{ns}$ & \multicolumn{2}{|c|}{$* *$} \\
\hline CV (\%) & 9 & 12 & 15 & 8 & \multicolumn{2}{|c|}{12} \\
\hline
\end{tabular}

(1)Means in the same column, followed by the same letter, are not different at $5 \%$ probability level by the Tukey's test; $\mathrm{Zn}_{0}$ and $\mathrm{Zn}_{10}$ : 0 and

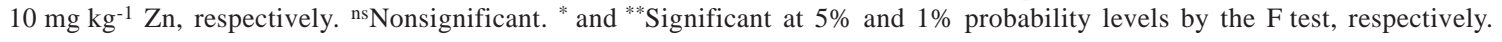


Zinc harvest index (ZnHI) was significantly influenced by soil Zn levels and genotypes, and interaction between soil Zn levels and genotypes was also highly significant (Table 1). The ZnHI indicates the quantity of $\mathrm{Zn}$ translocated to grain from the amount of $\mathrm{Zn}$ absorbed by the roots. $\mathrm{ZnHI}$ varied from 0.40 to 0.76 at the low Zn level, and 0.21 to 0.37 at the high Zn level. Average values across genotypes were 0.60 and 0.28 , respectively. The genotypes recorded higher $\mathrm{ZnHI}$ at low $\mathrm{Zn}$ level, than at high soil $\mathrm{Zn}$ level, and such differences are due to higher $\mathrm{Zn}$ accumulation in the shoot at the higher $\mathrm{Zn}$ level.

Zinc concentration in the shoot and grain was significantly affected by soil Zn levels, as well as genotype (Table 2). However, $\mathrm{Zn}$ and genotype interaction was only significant for $\mathrm{Zn}$ concentration in the shoot. Therefore, average values of $\mathrm{Zn}$ concentrations in the grain, at two levels of soil Zn, are presented. At the lower $\mathrm{Zn}$ level, average $\mathrm{Zn}$ concentration was $54 \mathrm{mg} \mathrm{kg}^{-1}$ and at the higher $\mathrm{Zn}$ level, it was $91 \mathrm{mg} \mathrm{kg}^{-1}$ in the shoot. Average $\mathrm{Zn}$ concentration in the grain of ten genotypes was $35 \mathrm{mg} \mathrm{kg}^{-1}$. This means that $\mathrm{Zn}$ concentration in rice shoot is higher than in grain. Fageria et al. (1997) also reported that Zn concentration in grain of upland rice is much lower than in straw.

Table 2. Zinc concentration ( $\mathrm{mg} \mathrm{kg}^{-1}$ ) in shoot at two $\mathrm{Zn}$ levels, grain Zn concentration ( $\mathrm{mg} \mathrm{kg}^{-1}$ ) and Zn recovery efficiency (ZnRE) across two $\mathrm{Zn}$ levels of ten upland rice genotypes ${ }^{(1)}$.

\begin{tabular}{|c|c|c|c|c|}
\hline \multirow[t]{2}{*}{ Genotype } & \multicolumn{2}{|c|}{$\mathrm{Zn}$ in shoot } & \multirow[t]{2}{*}{$\mathrm{Zn}$ in the grain } & \multirow[t]{2}{*}{ ZnRE (\%) } \\
\hline & $\mathrm{Zn}_{0}$ & $\mathrm{Zn}_{10}$ & & \\
\hline Bonança & 69 & $119 \mathrm{ab}$ & $39 \mathrm{ab}$ & $15.0 \mathrm{ab}$ \\
\hline Caiapó & 51 & $88 \mathrm{~b}$ & $41 \mathrm{a}$ & $14.6 \mathrm{ab}$ \\
\hline Canastra & 40 & $68 \mathrm{~b}$ & $38 \mathrm{abc}$ & $12.4 \mathrm{ab}$ \\
\hline Carajas & 48 & $87 \mathrm{~b}$ & 37 abcd & $13.3 \mathrm{ab}$ \\
\hline Carisma & 50 & $82 b$ & 37 abcd & $11.8 \mathrm{ab}$ \\
\hline CNA8540 & 45 & $72 b$ & 35 bcde & $10.4 \mathrm{~b}$ \\
\hline CNA8557 & 50 & $72 b$ & $30 \mathrm{ef}$ & $8.5 b$ \\
\hline Guarani & 94 & $176 \mathrm{a}$ & $32 \mathrm{de}$ & $23.1 \mathrm{a}$ \\
\hline Maravilha & 48 & $79 b$ & $33 \mathrm{cde}$ & $13.1 \mathrm{ab}$ \\
\hline IR42 & 48 & $68 \mathrm{~b}$ & $26 f$ & $8.3 b$ \\
\hline Average & 54 & 91 & 35 & 13.1 \\
\hline \multicolumn{5}{|l|}{ F test } \\
\hline Zn level & \multicolumn{2}{|c|}{$* *$} & $* *$ & ns \\
\hline Genotype (G) & \multicolumn{2}{|c|}{$*$} & $* *$ & $*$ \\
\hline $\mathrm{ZnxG}$ & \multicolumn{2}{|c|}{$* *$} & $\mathrm{~ns}$ & ns \\
\hline $\mathrm{CV}(\%)$ & \multicolumn{2}{|c|}{37} & 13 & 32 \\
\hline
\end{tabular}

(1)Means in the same column, followed by the same letter, are not

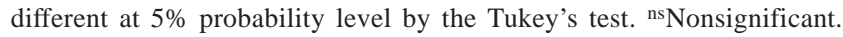
${ }^{*}$ and ${ }^{* *}$ Significant at $5 \%$ and $1 \%$ probability levels by the $\mathrm{F}$ test, respectively.
Zinc recovery efficiency (ZnRE) varied from 8.3\% to $23.1 \%$, with an average of $13 \%$ across ten genotypes (Table 2). Information on recovery efficiency by lowland rice genotypes is limited, and hence these results can not be compared with the published work. However, Mortvedt (1994) reported that crop recovery of applied micronutrients is relatively low (5\% to $10 \%$ ) compared to macronutrients (10\% to $50 \%$ ). Such low recovery of applied micronutrients is due to their uneven distribution in a soil because of low application rates, reaction with soil to form unavailable products and low mobility in soil.

Copper concentration in the plant tissue is reported to be in the range of 5 to $20 \mathrm{mg} \mathrm{kg}^{-1}$ dry weight of shoot, which is second lowest next to Mo among the micronutrients (Shimda, 1995; Wilkinson \& Grunes, 2000). The concentration of $\mathrm{Cu}$ in shoots at the lower soil Zn level was quite low, and even with the higher soil $\mathrm{Zn}$ level it was still bellow an adequate one (Table 3). Copper concentrations at higher soil Zn level were 83\% and $10 \%$ higher in shoot and grain, respectively, than with the lower soil Zn level. Manganese concentration in the plant tissue reported for normal growth was in the range of 50 to $100 \mathrm{mg} \mathrm{kg}^{-1}$ dry weight (Wilkinson \& Grunes, 2000). The observed Mn concentration in upland rice shoots was 31\% higher at higher soil $\mathrm{Zn}$ level than at lower soil $\mathrm{Zn}$ level. In grain, the increase in $\mathrm{Mn}$ concentration was $22 \%$ at higher soil $\mathrm{Zn}$ level as compared to lower $\mathrm{Zn}$ level. When supplied at adequate levels, $\mathrm{Zn}$ has positive effect on the uptake of $\mathrm{Cu}$ and Mn for upland rice grown on an Oxisol. Positive as well as negative interactions among micronutrients have been reported (Wilkinson \& Grunes, 2000). Levels of Zn in

Table 3. Influence of zinc on the concentrations ( $\left.\mathrm{mg} \mathrm{kg}^{-1}\right)$ of $\mathrm{Cu}, \mathrm{Mn}$ and $\mathrm{Fe}$ (shoot and grain) across ten upland rice genotypes $^{(1)}$.

\begin{tabular}{lccccc}
\hline \multirow{2}{*}{ Micronutrient } & \multicolumn{2}{c}{ Shoot } & & \multicolumn{2}{c}{ Grain } \\
\cline { 2 - 3 } \cline { 5 - 6 } & $\mathrm{Zn}_{0}$ & $\mathrm{Zn}_{10}$ & & $\mathrm{Zn}_{0}$ & $\mathrm{Zn}_{10}$ \\
\hline Copper & $2.30 \mathrm{~b}$ & $4.20 \mathrm{a}$ & & $11.70 \mathrm{~b}$ & $12.87 \mathrm{a}$ \\
Manganese & $236 \mathrm{~b}$ & $309 \mathrm{a}$ & & $27 \mathrm{~b}$ & $33 \mathrm{a}$ \\
Iron & $139 \mathrm{a}$ & $147 \mathrm{a}$ & & $31 \mathrm{a}$ & $28 \mathrm{a}$ \\
\hline
\end{tabular}

(1) Means in the same line, for each growth parameter, followed by the same letter, are not different at $5 \%$ probability level by the Tukey test. ${ }^{(2)} \mathrm{Zn}_{0}$ and $\mathrm{Zn}_{10}$ : no application and application of $10 \mathrm{mg} \mathrm{kg}^{-1} \mathrm{Zn}$, respectively. 
soil and plant significantly influenced the uptake of $\mathrm{Cu}$ and Mn, but did not affect the uptake of Fe by upland rice genotypes.

\section{Conclusions}

1. Upland rice genotypes differ significantly in relation to grain yield, yield components and Zn harvest index.

2. Numbers of panicles are of primary importance, followed by shoot dry matter and grain harvest index in relation to improving grain yield.

3. Zinc concentrations are higher in shoots than in grain, and $\mathrm{Zn}$ harvest index decreases with increasing soil Zn level.

\section{Acknowledgements}

To Drs. D.R. Morris and C.D. Foy, for their reviews of the manuscript.

\section{References}

EMBRAPA. Centro Nacional de Pesquisa de Solos. Manual de métodos de análise de solos 2.ed. Rio de Janeiro: Embrapa-CNPS, 1997. 212p.

FAGERIA, N.K. Nutrient management for upland rice production and sustainability. Communication in Soil Science and Plant Analysis, v.32, p.2603-2629, 2001.

FAGERIA, N.K.; BALIGAR, V.C. Lowland rice response to nitrogen fertilization. Communications in Soil Science and Plant Analysis, v.32, p.1405-1429, 2001.

FAGERIA, N.K.; BALIGAR, V.C. Response of common bean, upland rice, corn, wheat, and soybean to soil fertility of an oxisol. Journal of Plant Nutrition, v.20, p.1279-1289, 1997.

FAGERIA, N.K.; BALIGAR, V.C. Yield and yield components of lowland rice as influenced by timing of nitrogen fertilization. Journal of Plant Nutrition, v.22, p.23-32, 1999.
FAGERIA, N.K.; BALIGAR, V.C.; CLARK, R.B. Micronutrients in crop production. Advances in Agronomy, v.77, p.185-268, 2002.

FAGERIA, N.K.; BALIGAR, V.C.; JONES, C.A. Growth and mineral nutrition of field crops. $2^{\text {nd }}$ ed. New York: M. Dekker, 1997. 624p.

GOEDERT, W.J. Região dos cerrados: potencial agrícola e política para seu desenvolvimento. Pesquisa Agropecuária Brasileira, v.24, p.1-17, 1989.

GRAHAM, R.D.; RENGEL, Z. Genotypic variation in zinc uptake and utilization by plants. In: ROBSON, A.D. (Ed.). Zinc in soils and plants. Dordrecht: Kluwer Academic, 1993. p.107-118.

GRAVOIS, K.A.; McNEW, R.W. Genetic relationships among and selection for rice yield and yield components. Crop Science, v.33, p.249-252, 1993.

HAY, R.K.M. Harvest index: a review of its use in plant breeding and crop physiology. Annals of Applied Biology, v.126, p.197216, 1995.

LOPES, A.S. Solos sob cerrado: características, propriedades e manejo. Piracicaba: Potafos, 1983. 162p.

MORTVEDT, J.J. Needs for controlled-availability micronutrient fertilizers. Fertilizer Research, v.38, p.213-221, 1994.

ROBERTS, S.R.; HILLS, J.E.; BRANDON, D.M.; MILLER, B.C.; SCARDACI, S.C.; WICK, C.M.; WILLIAMS, J.F. Biological yield and harvest index in rice: nitrogen response of tall and semidwarf cultivars. Journal of Production Agriculture, v.6, p.585-588, 1993. SHIMDA, N. Deficiency and excess of micronutrient elements. In: MATSUO, T.; UMAZAWA, K.K.; ISHII, R.; ISHIHARA, K.; HIRTA, H. (Ed.). Science of the rice plant: physiology. Tokyo: Food and Agricultural Policy Research Center, 1995. v.1, p.412419.

SINCLAIR, T.R. Historical changes in harvest index and crop nitrogen accumulation. Crop Science, v.38, p.638-643, 1998.

SNYDER F.W.; CARLSON, G.E. Selecting for partitioning of photosynthetic products in crops. Advances in Agronomy, v.37, p.47-72, 1984.

WILKINSON, S.R.; GRUNES, D.L. Nutrient interactions in soil and plant nutrition. In: SUMNER, M.E. (Ed.). Handbook of soil science. Boca Raton: CRC, 2000. p.89-111.

YOSHIDA, S. Fundamentals of rice crop science. Los Baños: International Rice Research Institute, 1981. 269p. 